\title{
The Association of Cervical Length, Bacterial Vaginosis, Urinary Tract Infection and Premature Rupture of Membranes to The Imminent Preterm Labour
}

\author{
Hariyo Wirastomo Prajarto ${ }^{\star}$, Besari Adi Pramono \\ ${ }^{1}$ Resident Fellow, Departement of Obstetrics and Gynecology, Faculty of Medicine, Diponegoro University/Dr Kariadi \\ General Hospital Medical Center, Semarang \\ ${ }^{2}$ Fetomaternal Division, Departement of Obstetrics and Gynecology, Faculty of Medicine, Diponegoro University/Dr \\ Kariadi General HospitalMedical Center, Semarang
}

Keywords:

Bacterial vaginosis Cervical length Imminent preterm labor Premature rupture of membranes

Urinary tract infection

*) Correspondence to: hariyowpobsgin@gmail.c om

Article history:

Received 28-11-2020

Accepted $04-12-2020$

Availableonline10-12-2020

\begin{abstract}
Background: Research conducted at the Central General Hospital (RSUP) Dr. Kariadi Semarang in 2013 stated that out of 1,719 deliveries, $82(5 \%)$ were preterm labor cases. Although there are many predictors for predicting imminent preterm labour, the complete prediction and prevention have not been established. Prevention of preterm labor through screening is the key to antenatal care. Good early prediction on a premature labor will provide adequate antenatal surveillance and special interventions.

Objective: to analyze the relationship between cervical length, bacterial vaginosis, urinary tract infections, and premature rupture of membranes with the incidence of preterm labor

Methods: It is an observational analytic study in the form of the design of cross sectional with subject of pregnant women who experienced imminent preterm labour at gestational age 28-34 weeks and were treated at the ward of Obstetrics Gynaecology Hospital Dr. Kariadi Semarang and network hospital during the study period $(n=112)$. Subjects were assessed for the clinical risk (BV, premature rupture of the membrane, urinary tract infection) and sonography (cervical length). Statistical analysis was performed with paired t-test for normally distributed data and Mann Whitney if otherwise. Analysis of the relationship between variables and the incidence of preterm labor was carried out by the X 2 test

Results: From 112 subjects, it was found that the Prevalence Ratio (PR) for cervical length, bacterial vaginosis, urinary tract infections and premature rupture of membranes to the incidence of imminent preterm labor was 2.2;2.32;1.99 and 2.36 respectively. From the multivariate analysis, it was found that bacterial vaginosis and premature rupture of membranes were the most influencing factors for the incidence of imminent premature labor with Odd Ratios of 6.497 and 21.362 , respectively Conclusion: There is a relationship between cervical length $(\leq 25 \mathrm{~mm})$, bacterial vaginosis, urinary tract infections and premature rupture of membranes in the incidence of preterm labor.
\end{abstract}

DIMJ, 2020, 1(2), 39-45 DOI: https:/ / doi.org/10.14710/dimj.v1i2.9538

\section{Introduction}

Data from 2005 showed that babies born between 34 and 36 weeks of gestation have morbidity and mortality characteristics such as premature babies. Therefore, the current definition of preterm labor according to WHO is delivery that occurs between 20 weeks of gestation and gestation less than 37 weeks, counting from the first day of the last menstruation. ${ }^{1,2}$
By convention, gestational age is reported in complete weeks, i.e. seven days, thus 36 weeks 6 days gestation is reported as 36 weeks gestation. ${ }^{2}$ Gestational age is an important predictor of fetal survival and quality of life. Pregnancy is termed term if it lasts between 37 to 41 weeks counting 
from the first day of the last menstrual cycle on the 28-day cycle. Preterm labor itself is defined as delivery that occurs before the fetus is 37 weeks old. ${ }^{2}$

In Indonesia, the incidence of preterm birth cannot be ascertained. According to the 2013 Basic Health Research (Riskesdas) report, the prevalence of low birth weight babies (LBW) in Indonesia has decreased from $11.1 \%$ in 2010 to $10.2 \%$ in 2013 . This LBW figure does not absolutely represent the incidence of preterm delivery but can reflect roughly. Research conducted at the Central General Hospital (RSUP) Dr. Kariadi Semarang in 2013 stated that out of 1,719 deliveries, $82(5 \%)$ were preterm labor cases. $^{3-5}$

To address the problem of prematurity, it is important to identify high-risk pregnant women. Risk factors for preterm birth, namely: reproductive history (previous spontaneous preterm birth, antepartum haemorrhage, and premature rupture of membranes), cervical / uterine factors (cervical insufficiency, uterine abnormalities, uterine fibroids, and cervical excision in the treatment of cervical intraepithelial neoplasia), fetal factor (multi-fetal pregnancy, fetal anomaly, and polyhydramnios), infections (chorioamnionitis, bacteriuria, periodontal disease, and bacterial vaginosis), demographic factors (low socioeconomic status, low educational level, ethnicity, or maternal age $<18$ years or $>35$ years), lifestyle (smoking, drug use, stress, and physical violence), inadequate prenatal care, and low body weight both before pregnancy and during pregnancy. ${ }^{6,7}$

The diagnosis of preterm labor is based on clinical examination of uterine contractions and changes in the dilatation of the cervix. 8Uterine cervical changes can be the most efficient test for predicting preterm delivery and are the best predictors of assessing preterm birth $<34$ weeks in asymptomatic pregnant women, with the risk of preterm delivery increasing if cervical length $<15$ $\mathrm{mm}$. Several previous studies have also shown that transvaginal ultrasound of the uterine cervix can identify pregnant women with an increased risk of preterm birth. ${ }^{6.9}$

Although there are many predictors for predicting imminent preterm labour, the complete prediction and prevention have not been established. Prevention of premature labor through screening is the key to antenatal care. Early prediction on the occurrence of premature labor will enable health care provider to perform intensive antenatal surveillance and special interventions. ${ }^{2,9,10}$

Attempts were made to delay the occurrence of preterm labor in preterm labor such as giving tocolytics. Tocolytic covers a wide range of drugs that can slow down or suppress the uterine contraction. The benefits of this agent administration in preterm labor are to allow time for fetal lung maturation. Administration of antenatal corticosteroids (Antenatal Corticosteroid $=$ ACS) provide clinical effects and allow time for transfer to providers of intensive neonatal care facilities. ${ }^{11,12}$ This study is aimed to further analyze the relationship between each clinical risk (BV, UTI, PROM) and sonography (cervical length) with the incidence of imminent preterm labour.

\section{Method}

\section{Design, Time and Place}

The experiment was conducted in the period from June 2019 until the number of samples is fulfiled in the labour ward of Dr.Kariadi Semarang General Hospital and hospital networks, previously received approval from the Ethical Clearance Faculty of Medicine, University of Diponegoro, Hospital Dr. Kariadi Semarang.

\section{Sample}

Pregnant women 28-34 weeks of gestation who experience premature labor in the hospital ward and delivery room Dr. Kariadi Semarang and network hospitals in the study period that met the inclusion and exclusion criteria. Sampling was done by consecutive sampling.

\section{Data Analysis}

Data was analyzed using SPSS software. Analysis of the difference in the mean value of the variables between the unpaired test was performed if the data distribution was normal, if the data distribution was not normal, the Mann Whitney test was performed. The relationship between the free variable with a nominal or ordinal scale and the dependent variable with a nominal or ordinal scale was tested by the $\mathrm{X} 2$ test. Demographic characteristics need to be tested for homogeneity. If homogeneous, a multivariate test will be carried out.

\section{Results}

At the end of the study, 112 research subjects were obtained for analysis. The mean age of pregnant women in the subjects of this study was 28 years (28.71 $\pm 6,080$ years). With the average body mass index (BMI) in this study was $25,908 \pm 2.98 \mathrm{~kg} / \mathrm{m} 2$. Prevalence Ratio (PR) of cervical length, bacterial vaginosis, urinary tract infections, premature rupture of membranes to the incidence of imminent preterm labor is $2.2 ; 2.32 ; 1.99$; and 2.36 (Table 1) 
Table 1. The prevalence ratio of cervical length in labor for the incidence of imminent premature labor

\begin{tabular}{lcccc}
\hline \multicolumn{1}{c}{ Factors } & $\begin{array}{c}\text { Imminent } \\
\text { preterm labour }\end{array}$ & Total & $\begin{array}{c}\text { Prevalence } \\
(/ \mathbf{1 0 0})\end{array}$ & Prevalence Ratio/CI 95\% \\
\hline Cervical length $<\mathbf{2 5} \mathbf{~ m m}$ & 21 & 24 & 87.50 & $2,2 / 0.041-3,950$ \\
Bacterial Vaginosis & 27 & 32 & 84.38 & $2.327586 / 1,559-27,073$ \\
UTI & 23 & 29 & 79.31 & $1.994775 / 0,105-46,681$ \\
PROM & 19 & 20 & 95.00 & $2,362162 / 1,976-230,976$ \\
\hline Information: 95\% CI; 95\% Confide
\end{tabular}

Information: 95\% CI; 95\% Confidence Index

Table 2. Comparison of cervical length, bacterial vaginosis, urinary tract infections and premature rupture of membranes against the threat of preterm labor.

\begin{tabular}{|c|c|c|c|c|c|c|}
\hline \multirow{2}{*}{\multicolumn{2}{|c|}{ Exposure }} & \multicolumn{2}{|c|}{ PPI } & \multicolumn{2}{|c|}{ Non-PPI } & \multirow{2}{*}{$P$ value } \\
\hline & & $\mathrm{n}$ & $\%$ & $\mathrm{n}$ & $\%$ & \\
\hline \multirow{3}{*}{$\begin{array}{l}\text { Cervical } \\
\text { Length }\end{array}$} & $\leq 25 \mathrm{~mm}$ & 21 & 87.5 & 3 & 12.5 & \multirow{3}{*}{$0,000^{¥} *$} \\
\hline & $>25 \mathrm{~mm}$ & 35 & 39.8 & 53 & 60.2 & \\
\hline & Total & 56 & 50 & 56 & 50 & \\
\hline \multirow{3}{*}{ BV } & Yes & 27 & 84.4 & 5 & 15.6 & \multirow{3}{*}{$0,000^{¥} *$} \\
\hline & No & 29 & 36.3 & 51 & 63.8 & \\
\hline & Total & 56 & 50 & 56 & 50 & \\
\hline \multirow{3}{*}{ UTI } & Yes & 23 & 79.3 & 6 & 20.7 & \multirow{3}{*}{$0,000^{¥} *$} \\
\hline & No & 33 & 39.8 & 50 & 60.2 & \\
\hline & Total & 56 & 50 & 56 & 50 & \\
\hline \multirow{3}{*}{ KPD } & Yes & 19 & 95 & 1 & 5 & \multirow{3}{*}{$0,000^{£ *}$} \\
\hline & No & 37 & 40.2 & 55 & 59.8 & \\
\hline & Total & 56 & 50 & 56 & 50 & \\
\hline
\end{tabular}

Information:

PPI: Delivery of imminent preterm labour, BV: Bacterial Vaginosis, UTI: Urinary Tract Infection, PROM: Premature rupture of membranes

$£$ Fischer test, $¥$ Chi Square test, $*$ significant if $\mathrm{p}$ value $<0.05$

Statistical analysis was carried out to assess the significance of the main variables such as cervical length, bacterial vaginosis, urinary tract infection and premature rupture of membranes against the incidence of preterm labor with the Chi Square categorical test if it meets the requirements of the Fischer test or if it does not meet the requirements of the Chi Square test.

The results of statistical analysis using the categorical comparative test showed that all variables, such as cervical length, bacterial vaginosis, urinary tract infections and premature rupture of membranes significantly affected the threat of preterm labor.

\section{Multivariate Analysis}

From the results of the multivariate test, it was found that patients with bacterial vaginosis and premature rupture of membranes were the most influencing factors for the incidence of preterm imminent labor, with Odd Ratios of 6.497 and 21.362 times more likely to experience imminent premature labor, respectively.

Based on table 4, it shows that the more risk factors the subjects had, both cervical length $<25$ $\mathrm{mm}$, bacterial vaginosis, urinary tract infections and premature rupture of membranes, the more likely the subjects had PPIs. However, in the model above there are also $18.41 \%$ of subjects experiencing PPIs without any of the four risk factors above, this suggests that there are still other possible factors that could be investigated that influence the incidence of PPIs that were not yet in our study. 
Table 3. Logistic regression analysis of variables on the threat of preterm labor

\begin{tabular}{lccc}
\hline \multicolumn{1}{c}{ Variable } & $\mathbf{p}^{*}$ & Odd Ratio & $\mathbf{9 5 \%}$ CI \\
\hline Cervical length $\leq 25 \mathrm{~mm}$ & 0.436 & 0.404 & $0.041-3,950$ \\
Bacterial Vaginosis & $0.010^{*}$ & 6,497 & $1,559-27,073$ \\
Urinary tract infection & 0.610 & 2,210 & $0.105-46,681$ \\
Premature rupture of membranes & $0.012^{*}$ & 21,362 & $1,976-230,976$ \\
Positive Nitrite & 0.617 & 2,046 & $0.123-33,974$ \\
Leukocyte Esterase Positive & 0.248 & 2,222 & $0.574-8.607$ \\
Positive urine culture & 0850 & 1,156 & $0.257-5,187$ \\
Funneling & 0.998 & - & - \\
Age <20 years & 0.936 & - & - \\
Age 20-25 years & 0.999 & - & - \\
Age 26-30 years & 0.575 & 0.564 & $0.076-4.182$ \\
Age 31-35 years & 0.528 & 0.505 & $0.060-4.226$ \\
Age> 35 years & 0.371 & 0.422 & $0.064-2,792$ \\
\hline
\end{tabular}

Information: 95\% CI; Confidence Index 95\%, *significant p <0.05

Table 4. Probability and relative risk of cervical length (CL), BV, UTI and PROM to the incidence of PPI

\begin{tabular}{|c|c|c|}
\hline Risk Factor & PPI probability & RR Comparison \\
\hline Without risk factor & $18,41 \%$ & \\
\hline \multicolumn{3}{|l|}{ Single risk factor } \\
\hline Cervical length $<25 \mathrm{~mm}(\mathrm{PS}<25 \mathrm{~mm})$ & $44,35 \%$ & 2,41 \\
\hline BV & $72,45 \%$ & 3,94 \\
\hline UTI & $39,08 \%$ & 2,12 \\
\hline PROM & $82,56 \%$ & 4,49 \\
\hline \multicolumn{3}{|l|}{ Two risk factors } \\
\hline $\mathrm{CL}<25$ and $\mathrm{BV}$ & $93,09 \%$ & 5,06 \\
\hline $\mathrm{CL}<25$ and UTI & $69,38 \%$ & 3,77 \\
\hline $\mathrm{CL}<25$ and $\mathrm{PROM}$ & $94,36 \%$ & 5,13 \\
\hline BV and UTI & $88,21 \%$ & 4,79 \\
\hline $\mathrm{BV}$ and PROM & $98,22 \%$ & 5,34 \\
\hline UTI and PROM & $90,28 \%$ & 4,91 \\
\hline \multicolumn{3}{|l|}{ Three risk factors } \\
\hline $\mathrm{CL}<25, \mathrm{BV}$ and UTI & $96,35 \%$ & 5,24 \\
\hline $\mathrm{CL}<25, \mathrm{BV}$ and PROM & $99,49 \%$ & 5,41 \\
\hline $\mathrm{CL}<25, \mathrm{UTI}$ and PROM & $97,94 \%$ & 5,32 \\
\hline BV, UTI and PROM & $99,36 \%$ & 5,40 \\
\hline Four risk factors & $99,82 \%$ & 5,42 \\
\hline
\end{tabular}

\section{Discussion}

In our study, 112 study subjects measured cervical uterine length using ultrasonography and found 24 subjects with cervical length $\leq 25 \mathrm{~mm}$ $(21.43 \%)$ and 88 subjects with uterine cervix length> $25 \mathrm{~mm}(78.57 \%)$. Our findings suggest an association between cervical length and the incidence of imminent preterm labor. Our findings are in line with a previous retrospective cohort study using 1077 women who presented with imminent premature labor and found that cervical length has the best predictive accuracy rate that can be used at all gestational ages. ${ }^{13}$ However, in that research, it was found that the optimum cervical length limit was different at each gestational age, so the author suggested of setting the cervical length limit according to gestational age at the time of examination. 14 Another study described the cervical length limit used as $\geq 30 \mathrm{~mm}$ as measured at triage showing a significant association with the occurrence of spontaneous preterm labor. ${ }^{15}$ The sensitivity and specificity of cervical length as predictors of preterm labor will increase with the combination of other tests. The combination with the examination of the levels of the Metalloproteinase-9 Matrix (MMP-9) increased the sensitivity up to $90.9 \%$ and specificity up to $98.3 \%$. $^{16}$

Bacterial vaginosis is associated with the incidence of imminent preterm labor. These findings are in line with previous cohort studies. ${ }^{17-19}$ A cohort study with a sample of 234 pregnant women presenting with the threat of preterm labor, bacterial vaginosis and sexually transmitted infections were the most common causes identified in the study and caused preterm labor between 24 to 32 weeks' gestation. ${ }^{17}$ Two meta-analysis studies showing the 
association between bacterial vaginosis and preterm birth as well as to the spontaneous and maternal infection. ${ }^{18,19}$

Mechanisms of preterm labor due to infection are part of the breakdown of membrane integrity causing rupture (due to inflammation and the action of the protease enzymes), and include the release of endotoxin, exotoxin and prostaglandin stimulating cytokines. Two hypotheses put forward for bacterial vaginosis on preterm onset of labor, first; organisms that move ascending to the uterus and secondly, bacterial vaginosis is a marker of intrauterine colonization by similar organisms. ${ }^{20}$ Bacterial vaginosis in most studies can increase interleukin-1 beta levels in women, which in turn can lead to activation of Matrix Metalloproteinases (MMP) such as MMP-1 and MMP-9. Metalloproteinase matrix will act as an enzyme that degrades the extracellular matrix in the cervix and causes cervical weakness due to inflammatory processes. Apart from IL-1B, Il- 6 and IL-8 levels were also increased which induced a tissue inflammatory response. ${ }^{21}$

In theory, pathogenic bacteria can move ascending into the uterus and cause inflammation that leads to premature rupture of membranes, premature labor and fetal infection. ${ }^{22}$ In a previous case control study, it was found that $36.54 \%$ of pregnant women with urinary tract infections in the population of patients presenting with preterm labor. ${ }^{23}$ This is in line with a study of 272 patients in which $35.6 \%$ had positive urine cultures and $32.9 \%$ had preterm labor. ${ }^{24}$ Significant associations were also reported by previous investigators, $34 \%$ of urogenital infections were observed as a significant cause of preterm labor. Besides, genitourinary conditions identified as having a risk of preterm labor up to 3.77 times greater than that of the normal population. ${ }^{25} \mathrm{~A}$ study in Mexico showed that Eschericia coli was identified as a major cause of the threat of preterm labor with the majority of subjects eventually experiencing preterm labor. ${ }^{26}$

Regarding cytokines, amniotic fluid cytokines such as interleukin-1 (IL-1), interleukin-6 (IL-6), interleukin-8 (IL-8), tumor necrosis factor-alpha (TNF- $\alpha$ ), and granulocyte colony stimulating factor (G- CSF) is strongly associated with infection, premature rupture of membranes and preterm labor which cannot be stopped with tocolytic therapy. The cytokines together with prostaglandins will stimulate premature labor. ${ }^{22}$

Subjects with premature rupture of membranes were $95 \%$ found in cases of imminent premature labor, whereas in the group without threat of preterm labor, only 1 case of premature rupture of membranes was found. These findings support previous studies, where premature rupture of membranes was associated with the threat of preterm labor and abortion and was exacerbated by other factors such as age, smoking habits, low socio-economic status and low education levels. ${ }^{27}$ Research with a case control design also supports these findings, premature rupture of membranes is significantly associated with the incidence of preterm labor. Common risk factors for preterm labor include $21.4 \%$ gestational hypertension, stunting $<1.5 \mathrm{~m}(16.8 \%)$, premature rupture of membranes $(17.5 \%)$ and fetal distress $(14.9 \%) .{ }^{28}$

There is no single causative factor that can trigger premature rupture of membranes. Choriodesidual infection, inflammation and decreased levels of collagen in the membrane can cause premature rupture of the membranes. This could be due to genetic, nutritional, or external factors due to matrix degradation in inflammation. ${ }^{29}$ Immunocompromised condition in pregnancy and mechanical factors on the membrane can cause microbial invasion of the genital tract, activation of the host inflammatory response leading to lysis of the collagen mediated by mechanical disturbances. Disorders associated with thrombin activation, Matrix Metalloproteinase (MMP) and collagenolysis processes have also been reported in weakening the fetal membrane. ${ }^{30}$

One of the pathophysiological factors highlighted in premature rupture of membranes is oxidative stress and the formation of reactive oxygen species (ROS). Normal pregnancy is characterized by a redox balance between ROS and antioxidants. The main source of ROS is leakage of the electron transport system in the inner mitochondrial membrane during cellular respiration and release of immune cells during phagocytosis. Degradation of the collagenrich extracellular matrix that connects the amnion and chorion layers in the fetal membrane is a key factor in rupture of membranes. This process is mediated by MMP which catalyzes specific substrates. MMP activity is strictly regulated on the membrane at the stage of transmission, translation and posttranslational modification and its endogenous inhibitor, namely tissue specific inhibitor of metalloproteinase (TIMPs), the balance will result in a normal pregnancy. ${ }^{30}$

The calculation of the probability and relative risk of the four risk factors for cervical length, BV, UTI and PROM together will increase the risk of 5.42 times the incidence of PPI compared without the four risk factors, with a probability of $99.82 \%$. So, based on our study we found the relationship of cervical length, BV, UTI, PROM together to the incidence of PPI. 


\section{Conclusion}

There was an independent association between cervical length $(\leq 25 \mathrm{~mm})$, bacterial vaginosis, urinary tract infections and premature rupture of membranes in the incidence of PPI. Concomitant risk factors have also been shown to increase the incidence of PPIs.

\section{References}

1. Cunningham FG LK, Bloom SL, Hauth JC, Rouse DJ SC. Preterm Birth, 23 ed. In: GDWj DMT, editor. Williams Obstetrics. In: Williams obstetrics. 23th ed. New York: The McGraw Hill Companies; 2010. p. 804-21.

2. H W. Aspek Umum Prematuritas. In: Prematuritas. Bandung: PT Refika Adhitama; 2009. p. 1-6.

3. Himpunan Kedokteran Fetomaternal POGI. Panduan Pengelolaan Persalinan Preterm. Himpun Kedokt Fetomaternal POGI. 2011;

4. Kementrian Kesehatan Republik Indonesia. Profil Kesehatan Indonesia Tahun 2013. Kementrian Kesehat Republik Indones. 2014;

5. Suspimantari C. Faktor Risiko Prematuritas yang Berpengaruh terhadap Luaran Maternal dan Perinatal Berdasarkan Usia Kehamilan. Univ Diponegoro. 2014;

6. Lim K, Butt K, Crane JM et al. Ultrasonographic cervical length assessment in predicting preterm birth in singleton pregnancies. $\mathbf{J}$ Obstet Gynaecol Canada. 2011;33:486-99.

7. Arisoy R YM. Transvaginal sonographic evaluation of the cervix in asymptomatic singleton pregnancy and management options in short cervix. J Pregnancy. 2012;

8. Hayashi RH ME. How to diagnose preterm labor: a clinical dilemma. Clin Obstet Gynecol. 2000;43:768-77.

9. El-Ardat MA, Gavrankapetanovic F, El-Ardat KAA et al. Ultrasound measurement of cervical length as predictor of threatened preterm birth: a predictive model. Acta Inform Medica. 2014;22:306.

10. Khan KS HH. Risk screening for spontaneous preterm labour. Best Pract Res Clin Obstet Gynaecol. 2007;21:821-30.

11. Vogel JP, Nardin JM, Dowswell T, West HM OO. Combination of tocolytic agents for inhibiting preterm labour. Cochrane Libr. 2014;

12. Saleh Gargari S, Habibolahi M, Zonobi Z et al. Outcome of vaginal progesterone as a tocolytic agent: randomized clinical trial. ISRN Obstet Gynecol. 2012;

13. Hiersch L, Yogev Y, Domniz N, Meizner I, Bardin R, Melamed N. The role of cervical length in women with threatened preterm labor - is it a valid predictor at any gestational age? Am J Obstet Gynecol [Internet]. 2014; Available from: http://dx.doi.org/10.1016/j.ajog.2014.06.002

14. Ness A, Visintine J, Ricci E, Berghella V. Does knowledge of cervical length and fetal fibronectin affect management of women with threatened preterm labor? A randomized trial. 2007;(October):1-7.

15. Botsis D, Makrakis E, Papagianni V, Kouskouni E, Grigoriou O, Dendrinos S, et al. The value of cervical length and plasma proMMP-9 levels for the prediction of preterm delivery in pregnant women presenting with threatened preterm labor. Eur J Obstet Gynecol Reprod Biol. 2006;128(1-2):108-12.

16. Hoesli I, Tercanli S, Holzgreve W. Cervical length assessment by ultrasound as a predictor of preterm labour - Is there a role for routine screening? BJOG An Int J Obstet Gynaecol. 2003;110(SUPPL. 20):61-5.

17. McPheeters ML, Miller WC, Hartmann KE, Savitz DA, Kaufman JS, Garrett JM, et al. The epidemiology of threatened preterm labor: A prospective cohort study. Am J Obstet Gynecol. 2005;192(4):1325-9.

18. Subtil D, Denoit V, Gouëff F Le, Husson MO, Trivier D, Puech F. The role of bacterial vaginosis in preterm labor and preterm birth: $\mathrm{A}$ case-control study. Eur J Obstet Gynecol Reprod Biol. 2002;101(1):41-6.

19. Leitich H, Bodner-Adler B, Brunbauer $M$, Kaider A, Egarter C, Husslein P. Bacterial vaginosis as a risk factor for preterm delivery: A meta-analysis. Am J Obstet Gynecol. 2003;189(1):139-47.

20. Leitich H, Kiss H. Asymptomatic bacterial vaginosis and intermediate flora as risk factors for adverse pregnancy outcome. Best Pract Res Clin Obstet Gynaecol. 2007;21(3):375-90.

21. Goffinet F, Maillard F, Mihoubi N, Kayem G, Papiernik E, Cabrol D, et al. Bacterial vaginosis: Prevalence and predictive value for premature delivery and neonatal infection in women with preterm labour and intact membranes. Eur $\mathrm{J}$ Obstet Gynecol Reprod Biol. 2003;108(2):14651.

22. Lin GG, Scott JG. Bacterial vaginosis and the cervicovaginal immune response. Am J Reprod Immunol. 2012;100(2):130-4.

23. Verma I, Avasthi K, Berry V. Urogenital Infections as a Risk Factor for Preterm Labor: A Hospital-Based Case-Control Study. J Obstet Gynecol India. 2014;64(4):274-8. 
24. Acosta-Terriquez JE, Ramos-Martinez MA, Zamora-Aguilar LM, Murillo-Llanes J. [Prevalence of urinary tract infection in hospitalized patients with preterm labor]. Ginecol Obstet Mex. 2014 Nov;82(11):737-43.

25. Anjali P, Kshirsagar N. Urogenital Infections A Cause of Pre Term Labor. 2017;4(4):888-91.

26. Dautt-leyva JG, Canizalez-román A, Alfaro LFA, Gonzalez-ibarra F, Murillo-llanes J. Maternal and perinatal complications in pregnant women with urinary tract infection caused by Escherichia coli. 2018;1-7.

27. Hackenhaar AA, Albernaz EP, Fonseca TM V. Preterm premature rupture of the fetal membranes: association with sociodemographic factors and maternal genitourinary. J Pediatr (Rio J) [Internet]. 2014;90(2):197-202. Available from: http://dx.doi.org/10.1016/j.jped.2013.08.003
28. Rao CR, Ruiter LEE De, Bhat P, Kamath V, Kamath A, Bhat V. A Case-Control Study on Risk Factors for Preterm Deliveries in a Secondary Care Hospital, Southern India. 2014;2014.

29. Medina TM, Hill DA. Preterm premature rupture of membranes: Diagnosis and management. Am Fam Physician. 2006;73(4):659-64.

30. Dakkak W TA. 乳鼠心肌提取 HHS Public Access. Physiol Behav. 2017;176(5):139-48.

31. Pouraghaei, M., Moharamzadeh, P., Dibazar, S., Taghizadieh, A., Ala, A., Maroufi, P., Ghiasi, R.R. Hypodense area within epidural hematoma in brain CT scan; Prediction of active bleeding in epidural hematoma. Life Science Journal, 2013; 10 (1). 